\title{
17 Proclaiming and practicing pro-immigration values in Poland
}

\author{
A case study of Poznań
}

Izabella Main

\section{Introduction}

On June 20, 2018 when World Refugee Day was observed, the Polish Prime Minister Mateusz Morawiecki, representing the Law and Justice Party (PiS) announced that he would not take part - as agreed with representatives of other Visegrad countries - in a special working meeting of the European Commission devoted to refugee relocation in Europe. A week later the Prime Minister participated in a meeting of the European Council in Brussels. The meeting was focused on migration and prevention measures to reduce illegal migration (European Council, 2018). After debates on June 28 and 29, 2018, the Council accepted only voluntary participation of EU countries in refugee relocation programs.

EU heads of state or government agreed that on EU territory, those who are saved, should be taken charge of, on the basis of a shared effort, through a transfer in controlled centers. These centers are to be set up in member states, only on a voluntary basis, and should provide rapid and secure processing allowing to distinguish between irregular migrants, who will be returned, and those in need of international protection, for whom the principle of solidarity would apply.

(European Council 2018)

Prime Minister Morawiecki presented this decision as a 'big success of Poland,' concluding two years of negotiations in which Polish politicians representing government objected to any quotas on relocated refugees. The Polish media that supported the present government reported it as a 'huge, gigantic success of Poland', stressing the need to protect EU borders (Do Rzeczy June 29, 2018).

Such a political stance on support for refugees has been represented by the Law and Justice government in Poland, yet, I argue that the situation is far more nuanced when other social actors are considered. The anti-refugee and Islamophobic statements of politicians and the media in the period from 2015 to 2017 were studied in a number of articles and reports (Wrzosek 
2016; Adamczyk 2017; Pędziwiatr 2017; Goździak \& Márton 2018; Klaus et al. 2018). Western media also reported these incidents to a significant extent (Wigura 2016). However, the anti-refugee narrative was and is not the only narrative in Poland as I argue below.

In this chapter, I will address such questions as: what is the rationale of the current government's position on refugees? How it is transmitted to larger public? What are the consequences of the governmental position? What are the alternative responses (practices) of various groups to the 'refugee and migration crisis'? And what kind of pro-immigration values are referred to by groups and individuals advocating openness to migrants and refugees?

This chapter is based on an analysis of media coverage, public opinion polls, and fieldwork conducted in Poznań, a city in Western Poland. I decided to focus on Poznan for a variety of reasons. The migrant population of the city is growing, especially in recent years. The current Mayor of Poznań, Jacek Jaśkowiak, proclaimed support for migrants on a number of occasions. Additionally, I was able to observe first-hand several campaigns and actions in support of refugees and migrants that took place since 2015.

Despite the increase of the foreign-born population in Poznań, the number of migrants remained small until recently. In 2014, Poznan - with a population of 550,000 - had only around 2,600 foreign-born individuals registered as city residents and an additional 2,300 foreign-born students (Czerniejewska \& Main 2015). In 2017, the number of registered migrants reached 7,000, although some estimates doubled the number, indicating that as many as 15,000 foreign-born lived in Poznań (Urzad Miasta Poznania 2017). The majority came from the Ukraine, mainly to work and/or study. There are also small groups both from European Union countries and from Algeria, China, India, Korea, Saudi Arabia, and the United States. These groups have slightly increased the religious diversity ${ }^{1}$ of the city, although the newcomers are, like the rest of Poland, predominantly Catholic or Christian.

In this chapter, I will first discuss the attitude of the Polish government towards admitting refugees and the values they referred to in order to justify their positions. Second, I will outline the consequences of anti-refugee and anti-Muslim positions, visible in the results of public opinion polls and attacks against migrants. The next two parts are devoted to the Poznań city authorities' positions and local initiatives advocating openness and support to migrants and refugees. The chapter includes the discussion of values referred to by different social actors to justify views and actions in relation to refugees and migrants.

\section{The evolution of the Polish government's attitudes towards refugees}

In mid-2015, the coalition government of two parties - the Civic Platform (Platforma Obywatelska) and the People's Party (Stronnictwo Ludowe) committed to accepting some 7,000 refugees from Syria, Iraq, and Eritrea for 
settlement in Poland through the relocation program. During a televised speech, the then Prime Minister, Ewa Kopacz, declared:

Poland will accept only refugees, not economic migrants... we assure you that in the on-going negotiations, we set such conditions as separating refugees from economic migrants, sealing EU exterior borders, and controlling of accepted persons by our security services. Poland is and will be secure, Poland is and will be pro-European, Poland is and will be tolerant.

(Kopacz 2015)

Ewa Kopacz was referring to values such as security, pro-Europeanness, and tolerance. She stressed that in recent years Poland gained a lot as a result of European solidarity and that Europe expects solidarity from Poland. At that time, the Civic Platform was trying to both compromise with EU expectations and satisfy the Polish electorate. The government was therefore referring to solidarity and tolerance, yet also to securitization (Pędziwiatr $\&$ Legut 2017; Bałamut 2018). It was also emphasizing its pro-European position.

After the general election on October 25, 2015, the new government, controlled by the conservative Law and Justice Party (PiS), rejected previous commitments and openly confronted the EU on refugee relocation. It also promoted negative media coverage of the 'refugee and migration crisis' and fueled nationalist anti-refugee sentiments. This process started during the electoral campaign in 2015, when politicians of the PiS and KORWiN ${ }^{2}$ parties, as well as part of Kukiz' $15^{3}$ parties, addressed the issue of refugees using negative ideas and images. In October 2015, Jarosław Kaczyński - the leader of the Law and Justice Party - spoke of 'Different types of parasites, protozoa that are not dangerous in the bodies of these people [refugees], [but] could be dangerous here' (Kaczyński 2015). The fear of infectious diseases was combined with the issue of security. The discourse of contamination was reproduced at different sites and in different historical moments in the name of national security. Using the case of the Ebola virus, Carmela Murdocca (2003) has shown how the diseased and degenerate body has been produced in media to ensure the exclusion of racialized bodies, to control immigration, and to produce a subordinate group. Regardless of the available epidemiological evidence, metaphors of the plague and infection have been used to marginalize and keep out diaspora communities in host countries in an effort to 'exclude filth'. These fears of the immigrant body and its movement have been expressed in relation to infectious diseases: Avian flu, SARS, HIV/ AIDS, cholera, tuberculosis, and the plague (Harper \& Raman 2008).

In Kaczyński's speech, refugees were also portrayed as terrorists, especially in reference to the war in Syria and terrorist attacks in Europe. Kaczyński was by no means the first politician to refer to immigrants as parasites or criminals, such references were present in the United States in the 1990s and later. It has been argued that immigrants have become a new enemy in post- 
cold war period in the framework of Us vs Them. Furthermore, Sang Hea Kil convincingly shows the link between racism and nationalism:

From the physical body that experiences disgust and abjection projected symbolically onto the nation in a sexualize nightmare about crime, to the nation where the militarization of the border protects the imagined line between pure and impure, harmony and hostility, calm weather and cataclysm, nativist discourse maximizes the use of 'racist dirt fixations' and the nested scales in a veiled way to impose whiteness on the nation.

(Kil 2013: 19)

Racialization - along with stereotyping, objectification, and whiteness as a norm - was one of the strategies of othering present in both Polish and British mass media, as well as experienced by the othered individuals (Strani \& Szczepaniak-Kozak 2018).

Beata Szydło - who led the campaign of Andrzej Duda, the presidential nominee of PiS - mentioned security as a key concern of the government during a convention in September 2015. The issue of accepting and relocating refugees was mostly addressed in public speeches and media interviews, but hardly ever in official documents or electoral programs (Lason 2018). Szydło, the Prime Minister since November 16, 2015, not only questioned the numbers declared by the previous government $(7,000)$, but in January 2016 she stated that 'Christians should be given preference' (Pędziwiatr \& Legut 2017: 624). This statement corresponds with another theme in the government's stance on refugees, namely the assertion that refugees pose a threat to the Christian identity of Europe, and that the arrival of predominantly Muslim refugees would lead to the 'Islamization' of Europe and demographic changes in favor of Islam. The title of one of the articles published in a popular periodical - 'Islamic rape of Europe' $\left(w\right.$ Sieci $\left.^{4}\right)$ - exemplifies such attitudes. This caption attracted a lot of attention around the world. International newspapers, such as The Washington Post and The Independent, called the cover 'shocking, highlighting stereotypes used by the graphic designer and relating them to racist images of Jews and Blacks from the first half of the twentieth century' (Wigura 2016).

Polish politicians' Islamophobia was revived on many occasions. As pointed in the European Islamophobia report, in 2016, 'Islamophobic views become even more mainstream not only in politics, but also in the media, education, and other spheres of life' (Pędziwiatr 2017: 414). Poles have limited contact with the tiny Muslim population in Poland, yet they have started to imagine that there are many more Muslims than the actual numbers would suggest (Bobako 2017; Buchowski 2016). The state-owned media, transformed after the elections to promote the government's positions on migration, reinforced Islamophobic views by inviting critics of Islam to present Muslims as terrorists and manipulating media coverage of various events. 
These anti-refugee attitudes continued in subsequent years. Just before the regional elections on October 21, 2018, the Law and Justice Party aired an anti-refugee spot, which used very strong nationalistic rhetoric, on public television. The one-minute spot portrayed Poland of 2020 as a country ridden with Muslim refugee enclaves and citizens afraid to leave their houses after sunset due to prevalence of sexual attacks, aggression, and violence. Poland's Ombudsman and some other politicians objected to airing the spot, but to no avail. The media continued to broadcast nationalist and anti-refugee programing presenting refugees as a threat, emphasizing their supposed aggressiveness and criminality, or claiming their readiness to destroy the Christian civilization (see Goździak \& Márton 2018; Krzyżanowska \& Krzyżanowski 2018; Pędziwiatr 2018).

\section{'Refugees are coming' - moral panic in the making}

There were several consequences of such mis/mal-representation of refugees in Poland. First, there was a gradual change of the society's attitudes towards refugees and Muslims. Numerous public opinion polls about attitudes towards refugees in Poland were conducted in recent years. The analysis of the polls shows that very few people have no opinion about refugees, a mere four percent. This stands in sharp contrast with the standard 30 percent indicating indifference to political and social issues. This demonstrates that the topic of refugees has become very important to Poles. This topic resulted in increased interest in the social phenomenon of migration and heightened emotions. The situation of refugees was addressed on many occasions and used for many political ends. Furthermore, negative attitudes towards accepting refugees rapidly increased between May 2015 and December 2016. In 2015, only 21 percent of Poles did not want to offer protection to refugees, while in the following year as many as 52 percent of Poles were against offering refuge to asylum seekers. There has been a clear correlation between negative views of migrants or refugees and support for right-wing political parties (Adamczyk 2017: 331; CBOS 2017a; CBOS 2018). The only group of migrants welcomed by Poles would be those coming from the Ukraine. Fifty-five percent of Poles supported the admission of Ukrainians, according to public opinion pool from second half of 2016 (CBOS 2017b).

The second consequence of the anti-refugee discourse was an increase in anti-migrant sentiments and actions. This tendency is visible in the results of public opinion polls showing escalation of negative attitudes towards other nationalities, including migrants living in Poland (Cekiera 2017). For many Poles, there is no positive aspect of contact with migrants or refugees as a way to enrich the local culture (Łaciak \& Segeš Frelak 2018). This is not entirely surprising given the ethnic and religious homogeneity of the current Polish society (Buchowski 2016). The third consequence was an increase in racist and anti-immigrant attacks in recent years in Poland. The Never Again Association, monitoring such violence in its magazine, points out a 
continuously growing number of assaults on foreigners, taking place both in larger cities and smaller towns in Poland. Verbal abuses and physical attacks were directed against people who looked or behaved differently: individuals with darker complexion, speaking foreign languages, wearing different clothes, and/or perceived to be Muslim (Never Again Association 2019).

The previously described process of spreading and reinforcing anti-refugee, anti-migrant, and Islamophobic views and attitudes, and the resulting actions, can be explained using the concept of moral panic (Cohen 2017). Moral panic is characterized by disproportionate and inaccurate societal reactions to a serious situation or a threat. Barbara Pasamonik (2017) argues that 'Polish transformational panic about refugees is part of a broader culture war within the West - a clash of traditionalism and modernism, conservatism and liberalism of lifestyle, moral fundamentalism and relativism.' She stresses the conflict between pro-refugee narration, labelled as humanitarian, and anti-refugee one, labelled as nationalist. Both refer to moral values. As indicated above, politicians and groups promoting anti-refugee discourse referred to nationalist and/or Catholic values, emphasizing the value of ethnic and religious homogeneity and security. In the next part, I will look at actions and related values at the local level in Poznań.

\section{Responses to the 'refugee crisis' and values in the city of Poznań}

Research and writing about Polish responses to refugees seeking safe haven in Europe have focused mainly on the anti-refugee discourses and actions. However, some media outlets, reports, and empirical studies emphasized that there is a part of the Polish society that expresses solidarity and the basic humanitarian desire to help, but these efforts are often overshadowed by the anti-immigration discourse (see Tracz 2018). Some activists, members of the civil society and academia, have attempted to influence the debate through positive messages. It is worth mentioning the example of the Polish Day of Solidarity with Refugees, which took place on October 15, 2015, and involved 130 institutions (NGOs, theatres, museums, etc.) or grass root initiatives such as 'Chlebem i sola [With bread and salt]' aimed at improving the refugee situation in Poland and Europe (Eaciak \& Segeš Frelak 2018).

NGOs and informal groups have been the main social actors involved in supporting refugees and migrants in Poland since 1989. Their activities are often sponsored by international organizations and EU funds. Gradually some city mayors and councils have gotten more involved as a result of the recognition of the necessity to attract economic migrants to Poland and to better integrate newcomers already living in Poland. Several cities started to provide financial support to programs offering education, legal support, and integration activities for migrants. This support was needed especially after the current government limited the possibilities of receiving EU funds by NGOs supporting migrants and refugees (Prończuk 2017; Wyrwał 2017). 
One of the important recent initiatives was prepared by twelve city mayors representing the Civic Platform Party in Poland. On June 30, 2017, the cities of Białygostok, Bydgoszcz, Gdańsk, Kraków, Lublin, Łódź, Poznań, Rzeszów, Szczecin, Warszawa, and Wrocław signed a declaration promising to cooperate in supporting migration and migrants. Its fragments referring to values are particularly interesting:

Migrations are dynamic processes, common and - as the history of the world shows - inevitable, and in the context of the socio-demographic situation of our country - even beneficial. Polish cities have been open to migration processes and the diversity of residents for many years. ... We declare cooperation of cities through the exchange of experience and good practices, in order to ensure a high quality of life for all residents, in a spirit of solidarity and responsibility for the community that we create together with migrants. We declare openness and the will to partner in partnership with government administration, non-governmental organizations, and religious associations in the field of creating and implementing Polish migration policy, based on managing safe migration [bezpieczne migracje]. Together, we are able to develop an appropriate culture of accepting migrants, which will help develop our cities, make them more innovative and competitive.

(Deklaracja 2017)

The authors of this declaration - among them the Mayor of Poznan - stressed several values such as openness, diversity, solidarity, responsibility, acceptance, economic advantage (beneficial), and safety. The emphasis of these values can be seen as an expression of an on-going process of acceptance towards migrants and refugees but also as resistance to the conservative policies of the PiS government.

The city of Poznań established its first initiatives targeting migrants as early as 2009, when Poznan got involved in the 'Open Cities' project, organized by a consortium of several European cities and the British Council. The idea of an 'open city' was created by an international team within the EU program for the Urban Development Network. Wojciech Bauer, who coordinated this project in Poznan, stated that the goal of the project was 'to increase the level of openness of Poznan and its inhabitants, increase the attractiveness of the city and its labor market, attract foreign human capital, and better integrate immigrants' (Kościesza 2014). As result, the 2011 document 'Local plan of action' recommended that Poznań become an 'open city' (Sydow 2017). Subsequently, the city was a partner of an EU founded project 'AMIGA. An active approach to the labor market' (2013-2015), though the project was the result of an initiative of several researchers at Adam Mickiewicz University in Poznań. Migrant Info Point (MIP), a program offering information and support for migrants, ${ }^{5}$ was a direct outcome of the AMIGA project. In subsequent years, the city was a partner in several 
initiatives supporting migrants and refugees, such as Adopt a life vest, ${ }^{6}$ the Gallery without a home, ${ }^{7}$ and Airbag Poznan. ${ }^{8}$

On Saturday, July 18, 2015, a group of Poznań activists, including artists, academics, and anarchists, organized a pro-refugee demonstration 'In Solidarity with migrants [Solidarni z migrantami].' The Mayor, Jacek Jaśkowiak, joined the demonstration. This gesture of support from the city mayor showed his understanding of what it means to be an open city. Some of the statements during the demonstration directly referred to values, such as: 'We need to offer solidarity to people in need,' 'Poznań should be for all, Poland should be for all.' The last slogan actually undermined a popular statement of the right-wing radical movements: 'Poland for Poles.' During this demonstration, a counter-demonstration was organized by anti-Muslim organizations (Nyczka \& Żytnicki 2015). The day of October 15 was proclaimed as the Day of Solidarity with Refugees with events organized in many Polish cities in 2015 and 2016, including in Poznań (Dzień Solidarności 2016). In the name of international cooperation and human solidarity, meetings, social actions, artistic activities, workshops, discussions, lectures, exhibitions, happenings, film screenings and concerts were organized across Poland. The actions were very diverse, informing about the situation of refugees in various contexts, fundraising for refugees and solidarizing during demonstrations.

The government of Poznań was searching for new ways to present itself. After its self-presentation as open city and as city offering solidarity with migrants and refugees, in summer 2017 it started a campaign called 'Free City Poznań [Wolne Miasto Poznań]'. It consisted of t-shirts and promotional materials with the iconic inscription 'Free City Poznań' using symbols of religions and movements, such as the Christian cross, the Star of David, the Muslim crescent, a rainbow, a bike, a green leaf, a wheelchair, and a family, incorporated as part of the letters. The motto 'Free' was used to emphasize independence from the state government.

Another concept - 'respect' - was used during a social campaign named 'We Poznań 36.6 - Tolerance is not enough' in December 2017. Its aim was to oppose existing stereotypes and prejudices against refugees and migrants as well as other discriminated groups. The search for a common denominator to connect people was the starting point of this campaign. It was a body temperature of $36.6 \mathrm{C}$. The description read:

Respect for every human being and fight against discrimination - these are the main goals of the campaign, which has just been launched in Poznań. The action reminds us that it is not worth judging others based on stereotypes and superficial opinions.

The Constitution of the Republic of Poland guarantees every human being the right to respect for personal dignity - said Jacek Jaśkowiak, the city mayor. All discrimination is a violation of this right and leads to passivity and lack of response. It is time to change it. Through the 'We 
Poznań 36.6' campaign, we want to remind everyone that we are all equal, and respect is an inalienable right of every person

(My Poznań 36.6 2017)

The campaign was organized by the City Promotion Office, which worked with a private agency. On December 9, 2017, everyone could attend the event organized in the Old Market Square and accompanying the Ice Sculpture Festival in Poznań. Residents and tourists could see, in real time on a large screen, what they looked like in a thermal imaging camera.

All superficial differences lost their importance: clothing, skin color or sexual orientation disappeared - said the deputy director of the Mayor's Office, Patryk Pawełczak. What was left was the image of people who are the same, who have the same temperature and the same rights. In our campaign, it is all about rights.

(My Poznań 36.6 2017)

A movie promoting the campaign was also filmed during the event and later shown on public transportation and placed on YouTube channel. ${ }^{9}$ The narrator in the two-minute film stated that 'stereotypes disrupt our vision' and that 'the same thing can be called differently.' The words illustrating such cases accompanied the pictures: senior - grandma - katol [Catholic] moher [pejorative for conservative Catholic old women]; actress - girlfriend asfalt [pej. black]; student - hipster - biker - kujon [crammer] - ciapaty [pej. Indian/Bengali/etc.] - brudas [dirty]; boy - student - son - pedat [pej. gay]; family - children - socjat [pej. living on social services]. The final seconds contained the following message: 'In Poznań tolerance is not enough, in Poznań we return to respect.'

The campaign referred to the concepts of respect and dignity as grounded in the rights and laws guaranteed in the Polish Constitution (Chapter II, Article 31 and 32). This campaign can be seen as a move from solidarity with the Others, the needy, the suffering, the victims to a position when we, people, humans, are all the same, have the same body temperature, the same right to respect and dignity. It can be seen as an attempt to humanize all people who are discriminated against. The movie is not directly commenting on refugees yet there are many references to migrants and people who are not white. It ends with a call: 'If you encountered discrimination - react.'

\section{Civil society responses}

Several registered and informal civil society groups in Poznań started grassroot responses to anti-refugee and Islamophobic national government's decisions and statements. These responses were described by some activists as expressions of their individual responsibility for the world (Jarosz 2019). 
There were two types of actions taken in support of refugees. First, public campaigns, demonstrations, meetings, and workshops aimed at changing social attitudes, expressing solidarity, and openly supporting refugees and migrants. Second, there were a number of group and individual activities aimed at collecting financial support and material goods to be transported to refugee camps in Bulgaria, Greece, and Syria. These groups and actions represented humanitarianism abroad, since refugees were not admitted to Poland, yet their scope was limited due to lack of resources. Activists participating in crowdsourcing campaigns and those collecting material goods were often the same people. In this chapter, I focus on the public campaigns, demonstrations, and meetings because they invoked values.

There are no recent public opinion polls on the attitudes to refugees and migrants in Poznań (Mamzer 2011; Goździak \& Nowak 2012). The conclusion of the 2018 report 'Shaping fair cities: Integrating Agenda 2030 within local policies in times of great migration and refugees' flows,' based on 750 questionnaires with Poznań residents, read:

respondents strongly agreed with statements referring (in general terms) to human rights and those related to humanitarian aid - ensuring the possibility of satisfying the basic needs of people in a situation of higher necessity. Poznań residents agree that international action is needed to ensure safe and regulated migration flows, but at the same time they wanted to help foreigners in their place of residence, and grant Polish citizenship only to those who adapt to their way of life.

(Kwiecińska-Zdrenka 2018)

This quote shows that the solutions proposed by the current government regulated migration and support in the countries of conflict - are accepted by the majority of population. The restrictions on granting citizenship are particularly interesting. At present, there are no citizenship tests. Citizenship is granted on the basis of a specified length of registered residence and a certificate of Polish language knowledge.

The actions and campaigns in Poznan that aim at changing attitudes were mostly initiated by local NGOs. One of the campaigns named Adopt a life vest consisted of adoption of life vests, which were brought from the Kios Island to Poznań by Oxfam International for a street happening in the late 2016. In February-March of 2017, the Centre for Migration Studies and the Migrant Info Point decided to utilize the vests previously used by people crossing the Mediterranean Sea in an awareness raising campaign and display them in public spaces throughout the city: in cinema armchairs, at a coffee table in a local cafe, in a lecture hall, in a classroom, in a waiting room, and in an office. The often dirty, partly damaged adult and child size vests symbolized the absence of refugees in Poznań. The goal of the campaign was to encourage institutions and individuals 'to adopt' a vest to display it and organize meetings to talk about refugees. More than 40 institutions joined in 
(Akcja 'Zaadoptuj kamizelkę' 2017). None of the Catholic parishes decided to adopt a vest in spite of the organizers' encouragement ${ }^{10}$.

Labels with information were attached to the vests:

We do not know if those who were wearing them reached the shore safely, we do not know what happened to them. We know that they are not in Poland. But these vests remind us about their absence among us.

The action aimed at drawing attention to individuals who used these vests, to encourage people in Poznań to imagine such travel, and to think what it would take to make a decision to travel on a boat through the sea (Kwiatkowska 2017). The campaign aimed at drawing attention to the results of political decisions not to allow refugees to Poland, to raise awareness, to trigger emotions, to induce discussion, and to make society think about refugees. The organizers realized that anti-refugee discourse was present in the mass-media, which referred to anonymous 'waves,' threats, and problems, while people still crossed the sea risking their lives. The goal of the campaign was to strengthen the language of compassion and to empower people who did not agree with dominant anti-refugee discourse in the public sphere in Poland. The vests in cafes, cinemas, restaurants, schools, and offices represented people who would like to sit in these places and drink coffee, watch a movie, study, and live in a safe place. Absent refugees were represented as people with the same needs as the inhabitants of Poznań.

The message addressed to people in the Adopt a life vest campaign called them to be active:

We have the enormous privilege to live in a safe part of the world. The fact that we were born right here is a coincidence. However, what we do with this privilege is by no means accidental. It's a matter of our decision. Will we enjoy our well-being and hide from those who were by chance deprived of the possibility of a dignified life without fear or will urge solidarity?

(Akcja 'Zaadoptuj kamizelkę' 2017)

Comments were solicited from the people who encountered the life vests. A person sitting next to one of the life vests wrote about her emotions, saying: 'I sat with her at one table! We ate the soup. I wanted to ask her so much. So much to tell her. And this big, growing lump in my throat - a mixture of shame, grief, compassion, and rage.' Many reactions to the vests were very emotional, exactly as intended (I was part of the organizing group). The campaign was accepted with interest and enthusiasm to a greater degree than expected by the organizers, showing that people wanted to take a step and to help refugees.

During the campaign, several references were made to organizations supporting refuges, so that people could join them in their efforts. At that time, 
a number of NGOs and informal groups such as Humans of Aleppo, From Poznan with Love, Garage Sale, and others organized events, protests, happenings, discussions, and displays addressing the situation of migrants and refugees. These groups often mobilized for particular goals, such as collecting resources in Poznan or through crowdfunding portals, using social media, especially Facebook, and communicating and popularizing actions.

For example, From Poznan with Love was an action started by two individuals who were inspired after one of them returned from Nea Kavala camp in Greece where she volunteered and reported the enormous needs there. During a few weeks in December 2016, the action involved not only collecting money, but also the writing of letters to children in the camp by Polish pupils. It was estimated that half of the 800 people in the camp were children. The letters were translated to English and Arabic so that children in the camp could read them (Nyczka 2016). The money was to be used on the spot to provide food so that people in the camp could cook their own meals. The action organizers saw it as a way to bring back dignity, to give refugees a chance to make tea whenever they wanted. Since 2016, six Garage Sales were organized to support refugees and civil society organizations in different camps in Greece and Yemen. Recently, another Garage Sale was organized to collect money for an 'emergency fund' for few refugees living in Poland.$^{11}$ In this way Garage Sales were expression of activities exemplifying humanitarianism abroad and at home. Miriam Ticktin (2006) argued that humanitarianism (and human rights) is complexly constituted transnational institution, practice, and discursive regime, constructed around and about the ethical and moral imperative to bring relief to those suffering and to save lives.

Many activists I have spoken with mentioned the dehumanizing aspects of the government and the right-wing parties' campaigns. This discourse robbed refugees of their humanity. As Malkki (1996) wrote: 'Refugees stop being persons.' Thus, one of the main objectives of the above-mentioned actions was to refer to refugees as individuals with emotions, feelings, and needs. During one of the debates organized in Poznan, an invited speaker, Professor Anna Wolff-Powęska, said

We must ask ourselves questions about our humanity and politics: whose life has value for us? Who do we consider to be our neighbor, a human being? Why do we bend over one suffering person and not over another? We face the test of humanity.

(Salwacka 2017)

Values are an integral and important part of our lives, yet at the same time they are abstract things, which are difficult to talk about with any degree of specificity (Bednarek-Gilland 2017). This opinion is confirmed by my observations in the field - when talking with activists or reading media materials and documents there was hardly ever reference to values. The most commonly mentioned human values and rights included: right to dignity, 
respect, freedom, safe home. The motivations of people involved in these actions are often very general as well: 'so I am not ashamed in the future,' 'to give the next generation a future,' 'because we want to create a common vision of future.'

\section{Conclusions}

The perspectives and attitudes of the state government, the media, city authorities, and grass-roots initiatives towards refugees and migrants in Poland have been very diverse since 2015. The explanations, justifications, and values referred to in anti-refugee and pro-refugee actions and campaigns are in some cases contradictory. Discussions in Polish public sphere represented a case of strong polarization of opinions and attitudes towards refugees (Hall \& Mikulska-Jones 2016), which divided society, and in many cases groups and families.

The European Union has been a strong reference point since the EU-led actions and discussion influenced debates in Poland. At the same time, EUsponsored programs, and initiatives in support of migrants, especially third-country (non-EU) nationals - e.g. on the labor market - have been taking place for many years in Poland. These programs were aimed at the integration of migrants, including not only teaching them to speak the Polish language and how to function in every-day situations, but also addressing Polish society in order to change attitudes and support openness. Besides, many other activities were initiated and have been taking place without EU funding, supported by small grants (e.g. of the city of Poznań) and/or based on the volunteering of local groups and organizations, representing civil society.

Several actions described above were directly referring to diverse values solidarity, respect, openness, dignity. When I asked activists about the values which stimulated them to be involved, they stressed humanitarianism and human values. There were two major goals of the actions: 1) to support refugees and migrants (in Poland and abroad) and 2) to educate and activate Polish society to counterbalance negative discourse supported by the PiS government and state-supporting media. The result of the first was often 'a drop in the bucket,' given that measuring the outcomes of the actions aiming at social change is methodologically and epistemologically difficult, a longterm perspective is needed. Still there was an optimism among activists who started the innovative ways of supporting refugees and pro-refugee attitudes - they were based on a feeling of finding other involved people and groups across Poland, getting the support of some local authorities, and/or establishing international contacts with civil society individuals and groups. There were also, however, many concerns - about future politics, the modest involvement and support of society at large, the small chance of (and interest in) intercultural contacts and especially contacts with refugees which, in the opinion of activists, would decrease fear and de-humanizing practices. 
Finally, the rapidly growing Ukrainian migrant population in Poland has brought about new challenges. ${ }^{12}$

\section{Notes}

1 In 2005, the Muslim community created Muslim Cultural-Educational Centre, offering religious services, language courses, workshops and discussion meetings; new evangelical churches also organize their religious worship in Poznań.

2 KORWiN was a right-libertarian and Eurosceptic party established in 2015 by Janusz Korwin-Mikke.

3 Kukiz'15 - right wing and far-right political movement.

4 'wSieci' is a conservative weekly, established in 2012; in 2016 it had fourth place on the list of best-selling weeklies.

5 After 2015, the city of Poznań substantially contributed financially to its activities, since international programs became less available.

6 This action will be described in detail in next part of the chapter

7 'Gallery without a home' was an initiative of Migrant Info Point and the Centre for Migration Studies, financed by Oxfam International between November 2017 and March 2018. It consisted of workshops entitled 'I hear, feel, and understand. Stories of young refugees' for 8-10-year-old children in Poznań schools - pupils heard the stories and drew postcards for refugee children. These postcards were sent to refugee children in Italy and Greece. Their copies were displayed during the mobile exhibition entitled 'Gallery without a home.'

8 'Airbag Poznan' - a project organized in Poznań since 2018 aiming at increasing the security of foreigners in Poznan. Cafe, restaurant and pub personnel were trained in how to react to violence, report it to police and support victims until the arrival of policemen. The places of support are marked with an airbag symbol.

9 A leaflet was also prepared and distributed. The campaign Poznań 36.6 was later included into 'Cities4Europe - Europe for citizens: involve - inspire - impact' project, which includes 'a series of local events showcasing successful local initiatives that engage citizens, present ideas for new forms of democracy and map out a positive, common future' (Cities4Europe 2017).

10 This was not a surprise given the very ambivalent position of the Catholic clergy. See: Pędziwiatr 2018.

11 On countries of origin and number of refugees in Poland see Klaus, this volume.

12 See Klaus in this volume.

\section{References}

Adamczyk, A. (2017). 'The influx of persons seeking international protection in Poland compared to other EU states during the EU Migration Crisis (2014-2016),' Rocznik integracji europejskiej 11, pp. 329-341.

Akcja 'Zaadoptujkamizelkę' (2017). Centrum Badań Migracyjnych UAM. Available at www.cebam.amu.edu.pl/221-akcja-zaadoptuj-kamizelke.html

Bałamut, A. (2018). 'Polska wobec kryzysu imigracyjnego w Unii Europejskiej,' in Molo, B. (ed.) Migracja i uchodźstwo wyzwaniem dla bezpieczeństwa i wspótpracy międzynarodowej w XXI wieku, Kraków: Krakowska Akademia im. Andrzeja Frycza Modrzewskiego, pp. 103-120.

Bednarek-Gilland, A. (2017). Researching Values with Qualitative Methods. Empathy, Moral Boundaries and the Politics of Research. London and New York: Routledge. 
Bobako, M. (2017). Islamofobia jako technologia władzy. Studium z antropologii politycznej Kraków: Universitas.

Buchowski M. (2016). 'Making anthropology matter in the heyday of Islamophobia and the "Refugee Crisis": The case of Poland,' Ćeský lid (103), pp. 51-67.

CBOS (2017a). 'Stosunek Polaków do przyjmowania uchodźców,' Komunikat z badań nr 1. Warszawa: Centrum Badania Opinii Publicznej.

CBOS (2017b). 'Stosunek Polaków do przyjmowania uchodźców,' Komunikat z badań nr 44. Warszawa: Centrum Badania Opinii Publicznej.

CBOS (2018). 'Stosunek Polaków i Czechów do przyjmowania uchodźców,' Komunikat z badań nr 87. Warszawa: Centrum Badania Opinii Publicznej.

Cekiera, R. (2017). 'Między gościnnością a misoksenią - reperkusje kryzysu migracyjnego w Polsce,' Political Preferences 17, pp. 237-250.

Cities4Europe (2017). 'My Poznań 36.6'. Respect for every human being,' Available at http://cities4europe.eurocities.eu/eu-campaign/index.html\#/activity/700013

Cohen, S. (2017). Folk Devils and Moral Panics. The Creation of the Mods and Rockers. London and New York: Routledge.

Czerniejewska, I. \& Main, I. (2015). 'Statystyczny obraz zjawiska imigracji do Poznania,' in Bloch, N., Main, I., \& Sydow, K. (ed.) Nie dość użyteczni. Zmagania imigrantów na lokalnym rynku pracy. Poznań: Centrum Badań Migracyjnych, pp. 153-173.

Deklaracja (2017). 'Deklaracja 12 prezydentów dużych polskich miast: Migrację trzeba wspierać,' Polityka, 30 June. Available at: www.polityka.pl/tygodnikpolityka/kraj/ 1710710,1,deklaracja-12-prezydentow-duzych-polskich-miast-migracje-trzeba-wsp ierac.read

DzieńSolidarności (2016). Dzień Solidarności z Uchodźcami. Polska przeciw rasizmowi $i$ przemocy. Available at http://solidarnizuchodzcami.pl/apel/

European Council (2018). Meeting 28-29/06/2018. Main results. Available at www. consilium.europa.eu/en/meetings/european-council/2018/06/28-29/

Goździak, E. M. \& Márton, P. (2018). 'Where the wild things are: Fear of Islam and the anti-refugee rhetoric in Hungary and in Poland,' Central and Eastern European Migration Review 7, pp. 125-151.

Goździak, E. M. \& Nowak, L. (2012). 'Ten Obcy. Stosunek Wielkopolan do Cudzoziemców,' Przeglad Wielkopolski 1(95), pp. 17-28.

Hall, D. \& Mikulska-Jones, A. (2016). 'Uprzedzenia, strach czy niewiedza? Młodzi Polacy o powodach niechęci do przyjmowania uchodźców,' Analizy, Raporty, Ekspertyzy. Stowarzyszenie Interwencji Prawnej 1.

Harper, I. \& Raman, P. (2008). 'Less than human? Diaspora, disease and the question of citizenship,' International Migration 46(5), pp. 3-26.

Kil, S. H. (2013). 'A diseased body politic,' Cultural Studies 28(2), pp. 1-22.

Jarosz, E. (2019). 'Świat stał się za mały, żeby żyć wyłącznie dla siebie,' Rozmowa z Paulina Kuntze magazynrtv.com. Available at http://magazynrtv.com/wydanie-1/ wywiady/swiat-stal-sie-za-maly-zeby-zyc-wylacznie-dla-siebie-rozmowa-z/

Kaczyński, L. (2015). 'Kaczyński: Pasożyty i pierwotniaki w organizmach uchodźców groźne dla Polaków,' Newsweek. Available at: www.newsweek.pl/polska/jaroslaw-ka czynski-o-uchodzcach/89mwbx3

Klaus, W., Lévay, M., Rzeplińska, I., \& Scheinost, M. (2018). 'Refugees and asylum seekers in Central European Countries: Reality, politics and the creation of fear in societies,' in Kury, H. \& Redo, S. (eds) Refugees and Migrants in Law and Policy. Cham: Springer, pp. 1-34. 


\section{4}

Kopacz, E. (2015). 'Polska przyjmie tylko uchodźców, nie emigrantów ekonomicznych,' Polska Times. Available at: https://polskatimes.pl/ewa-kopacz-polska -przyjmie-uchodzcow-ale-nie-imigrantow-ekonomicznych/ar/8168870

Kościesza, K. (2014). Wywiad z Wojciechem Bauerem koordynatorem projektu Open Cities - Urzad Miasta Poznania. Available at: http://cw.org.pl/aktualnosci/ 97-wywiad-z-wojciechem-bauerem-koordynatorem-projektu-open-cities-urzad-mia sta-poznania

Krzyżanowska, N. \& Krzyżanowski, M. (2018). "Crisis” and migration in Poland: Discursive shifts, anti-pluralism and the politicisation of exclusion,' Sociology 52(3), pp. 612-618.

Kwiatkowska, A. (2017). 'Akcja "Zaadoptuj kamizelkę” przypomni o uchodźcach', Gazeta Wyborcza, 3 February. Available at: http://poznan.wyborcza.pl/poznan/ 7,36001,21331753,akcja-zaadoptuj-kamizelke-przypomni-o-uchodzcach.html

Kwiecińska-Zdrenka, M. (2018). Tworzenie Sprawiedliwych Miast - właczanie Agendy 2030 w polityki na poziomie lokalnym w czasach wielkich migracji i uchodźstwa. Toruń: Pracownia Badań Soma.

Łaciak, B. \& Segeš Frelak, J. (2018). The Wages of Fear. Attitudes Towards Refugees and Migrants in Poland. Warszawa: Instytut Spraw Publicznych.

Lasoń, M. (2018). 'Stanowisko polskich partii politycznych wobec problemu uchodźstwa i imigracji w drugiej dekadzie XXI wieku,' in Molo, B. (ed.) Migracja i uchodźstwo wyzwaniem dla bezpieczeństwa $i$ wspótpracy międzynarodowej w XXI wieku. Kraków: Krakowska Akademia im. Andrzeja Frycza Modrzewskiego, pp. 89-102.

Malkki, L. (1996). 'Speechless emissaries: Refugees, humanitarianism, and dehistoricization,' Cultural Anthropology 11(3), pp. 377-404

Mamzer, H. (2011). Czy warto ufać obcym? Poznań: Wydawnictwo Naukowe UAM.

Murdocca, C. (2003). 'When ebola came to Canada: Race and the making of the respectable body,' Atlantis 27(2), pp. 24-31.

My Poznań 36.6 (2017). Kampanie społeczne.pl. Available at: http://kampaniespoleczne. $\mathrm{pl} / \mathrm{my}$-poznan-366-walka-o-szacunek-dla-kazdego-czlowieka/ and www.youtube. $\mathrm{com} /$ watch? $\mathrm{v}=\mathrm{D} 46 \mathrm{DO} \mathrm{v} 4 \mathrm{CC} 44$

Never Again Association (2019). Selection of Islamophobic Events (for 2017-2018) Monitored in the 'Brown Book' Monitoring by the 'NEVER AGAIN' Association. Available at: www.nigdywiecej.org

Nyczka, T. (2016). "Wish you good luck and sunny days” Dzieci z Poznania piszą listy do swoich rówieśników uchodźców,' Gazeta Wyborcza, 18 December. Available at: http://poznan.wyborcza.pl/poznan/1,36001,21138828,i-wish-you-good-luck-a nd-sunny-days-dzieci-z-poznania-pisza.html

Nyczka, T. \& Żytnicki, P. (2015). 'Przeciwnicy i obrońcy imigrantów pikietowali w Poznaniu,' Gazeta Wyborcza, 18. July. Available at: http://poznan.wyborcza.pl/p oznan/1,36001,18386944,przeciwnicy-i-obroncy-imigrantow-pikietowali-w-pozna niu-przez.html

Pasamonik, B. (2017). 'Moral panic about refugees in Poland as a manifestation of cultural transformation,' Multicultural Studies 1, pp. 87-101.

Pędziwiatr, K. \& Legut, A. (2017). 'Polskie rządy wobec unijnej strategii na rzecz przeciwdziałania kryzysowi migracyjnemu,' in Wojtaszczyk, K. \& Szymańska, J. (eds) Uchodźcy w Europie. Uwarunkowania, istota, następstwa. Warszawa: Oficyna Wydawnicza Aspraa J-R, pp. 608-628.

Pędziwiatr, K. (2017). Islamophobia in Poland. National Report. Available at: www.islam ophobiaeurope.com/wp-content/uploads/2017/03/POLAND.pdf 
Pędziwiatr, K. (2018). 'The Catholic Church in Poland on Muslims and Islam,' Patterns of Prejudice 52(5), pp. 461-478.

Prończuk, M. (2017). Od dwóch lat rzad PiS blokuje środki unijne dla NGO-sów pomagajacych migrantom w Polsce. Za to daje $50 \mathrm{mln}$ euro na ,pomoc na miejscu.” Available at: https://oko.press/rzad-pis-daje-50-mln-euro-pomoc-miejscu-blokuje-srodki-unijnedla-ngo-sow-pomagajacych-migrantom-polsce/

Salwacka, S. (2017). “"Kogo uznajemy za bliźniego?” Debata, jak rozmawiać o uchodźcach. Może właśnie tak?' Gazeta wyborcza, 10 December. Available at: http://poznan.wyborcza.pl/poznan/7,36001,22764525,kogo-uznajemy-za-blizniegodebata-jak-rozmawiac-o-uchodzcach.html

Strani, K. \& Szczepaniak-Kozak, A. (2018). 'Strategies of othering through discursive practices: Examples from the UK and Poland,' Lodz Papers in Pragmatics 14(1), pp. $163-179$.

Sydow, K. (2017). '(Nie)widzialni mieszkańcy. Dyskurs o imigrantach i roli miasta w ich wspieraniu na przykładzie Poznania,' Studia Migracyjne - Przeglad Polonijny 2 (164), pp. 143-165.

Ticktin, M. (2006). 'Where ethics and politics meet: The violence of humanitarianism in France,' American Ethnologist 33(1), pp. 33-49.

Tracz, E. (2018). 'Stowarzyszenie Lepszy Swiat, "Tańczymy dla Syrii,” "Każdy może być mostem”,' in Kuligowski, W. (ed.), Miejsce oporu. O kontrkulturach kultury polskiej. Poznań: Biblioteka Czasu Kultury, pp. 149-156.

UrządMiastaPoznania (2017). Cudzoziemcy w Poznaniu. Available at: www.poznan.pl/m $\mathrm{im} / \mathrm{s} 8 \mathrm{a} /$ news/cudzoziemcy-w-poznaniu,110641.html-

Wigura, K (2016). Poland's Islamophobia. Available at: https://carnegieeurope.eu/stra tegiceurope/63892

Wrzosek, T. (2016). 'Discourse about refugees as a symptom of solidarity crisis,' Journal of Modern Science 1(28), pp. 411-430.

Wyrwał, M. (2017). Organizacje pozarzadowe na celowniku PiS. Mają dość, będa się bronić onet.pl. Available at: https://wiadomosci.onet.pl/tylko-w-onecie/organizacje-p ozarzadowe-na-celowniku-pis-maja-dosc-beda-sie-bronic/6mv1h1k 